\title{
OBITUARIES
}

\section{FELIX LAGRANGE}

The death of PROfessor Felix LAgrange has removed one of the most distinguished ophthalmic surgeons of the present day. He had recently retired from the Professorship of Ophthalmology at the University of Bordeaux to reside in Paris. At the beginning of his career he served for ten years as a military surgeon, and then took up the serious study of ophthalmology. At first his interest was directed to errors of refraction and to strabismus, later he published his monumental work on tumours of the eye and orbit. But he will be known pre-eminently as having introduced the operation of sclerectomy in the treatment of glaucoma, in 1906.

In 1927, on his seventieth birthday, a volume was published in his honour by his pupils and friends containing the more important extracts from his writings on ophthalmology, as well as other material.

Although a noted controversialist on ophthalmic matters where he considered some principle at stake, he was a sympathetic and sincere friend to those who knew him.

\section{MARC LANDOLT}

DR. MARC LANDOLT has met a tragic death by drowning. While sailing on the Seine with his two children his boat was capsized. He was able to bring the children to the boat and they were saved, but he himself became exhausted and was lost.

He was the elder son of the late Dr. Edmond Landolt who was an honorary member of the Ophthalmological Society of the United Kingdom, and a Bowman Lecturer, and was himself a member of the Society. In Paris he was a distinguished ophthalmic surgeon.

The sincere sympathy of all members of the Ophthalmological Society is extended to his family.

\section{NOTES}

Appointments

MR. J. S. ARKLE, has been appointed Honorary Ophthalmic Surgeon to the Royal Victoria Infirmary, Newcastle-on-Tyne. 